University of Nebraska - Lincoln

DigitalCommons@University of Nebraska - Lincoln

Faculty Publications, Department of Psychology

Psychology, Department of

2008

Signs for the Future of Civil Justice Research

Brian H. Bornstein

University of Nebraska-Lincoln, bbornstein2@unl.edu

Follow this and additional works at: https://digitalcommons.unl.edu/psychfacpub

Part of the Psychiatry and Psychology Commons

Bornstein, Brian H., "Signs for the Future of Civil Justice Research" (2008). Faculty Publications, Department of Psychology. 343.

https://digitalcommons.unl.edu/psychfacpub/343

This Article is brought to you for free and open access by the Psychology, Department of at DigitalCommons@University of Nebraska - Lincoln. It has been accepted for inclusion in Faculty Publications, Department of Psychology by an authorized administrator of DigitalCommons@University of Nebraska - Lincoln. 


\title{
Signs for the Future of Civil Justice Research
}

\author{
Brian H. Bornstein
}

The chapters in the present volume [Civil Juries and Civil Justice (New York: Springer, 2008)] provide a number of signs for the future of civil justice research. Many of the signs are favorable and point to continued fruitful collaborations between legal and psychological researchers on pressing topics in the justice arena with important policy implications; yet the contributions also highlight several gaps in the literature, data limitations, and false steps. In other words, some of the signs are not-so-favorable, and there is still much work to be done. In this concluding commentary, I identify the major portents for the future, both good and bad.

\section{Favorable Signs}

This book itself is an indication that the field is in good shape. ${ }^{1}$ The book will rise or fall on its own merits, but the fact that the book-and the conference that spawned it-attracted a stellar group of talented researchers and a leading publisher shows that there is a market for this kind of research. As noted in the Preface, disputes over the responsibility for injuries, and consequent attempts to attain justice, are an everyday occurrence. Most of these disputes do not ultimately result in trial by jury. As mentioned in several chapters, jury trials are rare, and some of the more controversial elements and types of trials (e.g., punitive damages, medical malpractice) are especially uncommon; yet juries are nonetheless such a central feature of the American civil justice system, with such profound ripple effects throughout society (influencing the behavior of consumers, manufacturers, insurers, policy-makers, and others), that their study is a worthy enterprise. A number of recent books

${ }^{1}$ This is, of course, a rather immodest claim for an editor to make about his own book, which I recognize and for which I ask the reader's indulgence.

Published in B. H. Bornstein et al. (eds.), Civil Juries and Civil Justice (New York: Springer, 2008), pp. 273-280. Copyright (C) Springer 2008. Used by permission.

Correspondence-B. H. Bornstein, Department of Psychology, 328 Burnett Hall, University of Nebraska-Lincoln, Lincoln NE 68588-0308, email bbornstein2@unl.edu 
on juries attest to the attention that they receive from researchers, the media, and the public (e.g., Abramson, 1994; Greene \& Bornstein, 2003; Jonakait, 2003; Sunstein, Hastie, Payne, Schkade, \& Viscusi, 2002; van Koppen \& Penrod, 2003; Vidmar \& Hans, 2007). ${ }^{2}$

Other signs exist that civil justice research is a vibrant field. The membership and conference attendance of leading interdisciplinary organizations, such as the American Psychology-Law Society and Law and Society Association, have grown steadily in recent years. Journals that frequently publish jury and related research, such as Law and Human Behavior, Behavioral Sciences and the Law, Psychology, Public Policy, and Law, and Psychology, Crime, and Law, have seen their submission numbers and impact factors rise. Law journals are increasingly publishing empirical scholarship, and "empirical legal studies" has become its own subdiscipline with its own journal, the Journal of Empirical Legal Studies, which appeared in 2004. To some extent, then, the field has been the beneficiary of the growth of law-and-psychology and law-and-social-science more broadly (see, e.g., Blumenthal, 2002; Ogloff \& Finkelman, 1999).

No doubt part of this growth reflects the fact that the jury system is being considered, adopted, or used more widely in a number of countries besides the U.S. and U.K. (e.g., Germany, Japan, Korea, Spain, Russia; see Kaplan \& Martin, 2006; Vidmar, 2000). Interestingly, and somewhat ironically, this movement toward the increasing use of juries in much of the world comes at a time when jury trials are on the decline in the U.S. (Galanter, 2004; Hans, 2006). Some other countries also employ lay judges, who in terms of knowledge, training, and experience are somewhere between jurors and professional judges; and empirical research has recently begun to focus on this class of legal decision maker (e.g., Bliesener, 2006; Diamond, 2003). Like lay judges, professional judges behave similarly to jurors in many respects (Robbennolt, 2005), but there are differences between these two types of legal decision makers as well (Diamond, 2003; Guthrie, Rachlinski, \& Wistrich, 2001). As jurors are not the only factfinders who resolve disputes at trial, it is encouraging that more research is focusing on these other decision makers as well.

The study of other kinds of legal decision makers has required the development and adoption of new research methods. For example, it is harder (though not impossible) to get judges to act as "mock judges" and read or view a simulated trial than it is to get college undergraduates to serve as mock jurors. Thus, the bulk of legal decision making research involves student mock jurors who read a simulated trial (Bornstein, 1999). The limitations, as well as the advantages, of jury simulations as a research tool have

${ }^{2}$ It is not a coincidence that some of these books have authors who are also contributors to the present volume. The list is selective and, in addition to omitting other scholarly works, leaves out the large number of novels about juries and books written, in some cases by jurors themselves, about individual well-publicized jury trials. The volume of these works also attests to the public's seemingly insatiable appetite for information on juries. 
been amply demonstrated (Bornstein, 1999; Bornstein \& McCabe, 2005; Diamond, 1997; Kerr \& Bray, 2005; Vidmar, this volume).

The use of diverse methodologies, such as juror interviews and case studies, is increasing, as illustrated by some of the selections in this book (see chapters by Vidmar and Hans). The increase in the number of archival analyses of actual jury verdicts, as exemplified by the empirical legal studies movement, also contributes to this diversity (see chapters by Sharkey, Eisenberg et al., and Poser). Field studies are another valuable piece of the puzzle, as they afford a degree of experimental control within a real-world context; but they are difficult and expensive to conduct and therefore rare. Using multiple methodologies to investigate the same issue is valuable because of the principle of convergent validity (Wiener, this volume); simply put, one can be more confident in the "truth" of some finding if it has been demonstrated across multiple contexts or exemplars using a variety of techniques. ${ }^{3}$ The increasing use of diverse research methods is clearly a good sign for the field, but as Vidmar (this volume) points out, researchers should use more ecologically valid methods more of the time.

\section{Not-So-Favorable Signs}

Part of the allure of studying jurors is that in addition to performing research that has policy implications, the jury is an ideal laboratory within which to study basic psychological processes such as decision making, hypothesis testing, persuasion, and group dynamics (Kerr \& Bray, 2005). Thus, jury researchers have, in a very real sense, the best of both worlds: the opportunity to make scientific as well as practical contributions. Many, if not most, researchers would agree that the best possible sign for civil justice research would be that the research is having some sort of real-world impact. Indeed, the best sort of psycholegal research adheres to a model of "social analytic jurisprudence," which combines legal and psychological analysis of legal doctrines with empirical research methods to bear on law and policy (Wiener, 2007). Empirical research on juries is critical to the proper establishment of policies governing jury trials, such as requirements regarding a jury's size, composition, decision rule, and other procedures (Saks, 1989, 1992). As Bornstein and Robicheaux describe in their introductory chapter, the tort reform debate has become increasingly data-driven, which is a good thing; nonetheless, legislators still evince a disturbing tendency to enact reforms in the absence of data demonstrating their effectiveness. Perhaps not surprisingly,

\footnotetext{
${ }^{3}$ There are never any guarantees, and there are no conventions for how to weigh conflicting findings. Findings can be contradictory not only across research methods but within a particular method depending on a variety of factors, such as assumptions, choice of data set, and analytic techniques (see Eisenberg et al., this volume).
} 
some of these non-empirically-based reforms have turned out to be counterproductive. Unintended effects can occur, at least under some circumstances, for such reform measures as caps (Robbennolt \& Studebaker, 1999; Sharkey, 2005; Sharkey, this volume) and split-recovery statutes (Sharkey, 2003).

There is also little evidence that empirical social scientific research is influencing the courts. For example, civil jury researchers submitted amicus curiae briefs in the two most recent punitive damages cases decided by the U.S. Supreme Court (Philip Morris USA v. Williams, 2007; State Farm Mutual Automobile Insurance Company v. Campbell, 2003), but neither opinion cited the brief, and in both cases the respondent (in support of whom the brief was submitted) lost. ${ }^{4}$

It is interesting to consider why jury research has had relatively little impact on the courts, whereas other experimental psychological research, such as the study of eyewitness memory, has made significant inroads (Benton, McDonnell, Ross, Thomas, \& Bradshaw, 2007; Technical Working Group for Eyewitness Evidence, 1999). ${ }^{5}$ In part, it seems to reflect an expectation that jurors can make the sorts of decisions required in civil cases (e.g., negligence, damages) just fine despite receiving little guidance (Greene \& Bornstein, 2000). Attorneys themselves are aware that it is not all common sense-hence the rise of trial consulting in civil cases (Bornstein \& Greene, in press; Hastie, this volume).

Rather than hiring consultants or retaining experts, wouldn't it be better, and more efficient, to train the attorneys themselves? Even though expert testimony, often of a scientific and/or experimental nature, is quite common in trials nowadays (Vidmar, this volume), few law schools offer instruction in scientific research methods or statistics. A survey of new law school course offerings (1994-1997) conducted by the Association of American Law Schools that reported the top 25 areas of curricular growth had no entries for statistics, research methods, or scientific practice (Merritt \& Cihon, 1997). However, an entry for "nonlegal skills" under "additional areas of potential curricular growth" did include 10 courses (from 83 law schools) on "quantitative methods, statistics, or social science techniques" (Merritt \& Cihon, p. 561). Thus, although most law students still finish law school without any significant empirical training, there are signs of progress. ${ }^{6}$ This is not to say, of course, that having lawyers with a modicum of scientific or methodologi-

${ }^{4}$ The present author signed the Philip Morris brief, and several other contributors to the present volume also signed one or both briefs.

${ }^{5}$ Although it has had little impact on caselaw, jury research has contributed to some procedural changes. For example, findings demonstrating poor comprehension of judge's instructions by jurors have contributed to the revision of instructions by some states, such as California (Miller \& Bornstein, 2004; Post, 2004).

${ }^{6} \mathrm{It}$ is possible, of course, that more courses have been added in the 10 years since this survey was conducted, a possibility corroborated by an informal survey done recently by Robert Lawless, Jennifer Robbennolt, and Thomas Ulen (Robbennolt, personal communication), who are preparing a textbook on the topic (Lawless, Robbennolt, \& Ulen, in press). 
cal training would obviate the need for consultants or experts in all cases; but it would undoubtedly reduce attorneys' reliance on them, and it would enable them to make better use of their services when they were retained.

One of the biggest shortcomings in civil justice research, as a field, is its overemphasis on jury behavior to the near exclusion of alternative methods of dispute resolution. Several chapters, particularly those in Section IV, highlight this shortcoming. As Tomkins and Applequist (this volume) note, there are many aspects of justice: distributive, procedural, restorative, and retributive, to which one could also add interactional (Robbennolt, this volume) and corrective (Sheinman, 2003; see generally, Tyler, Boeckmann, Smith, \& Huo, 1997). These various aspects of justice are all implicated in dispute resolution at trial, but their principles can also be employed to understand civil dispute resolution outside the courtroom litigation context, where it occurs much more often. There are lots of civil disputes, and most of them are resolved without a trial, by some alternative means. Not only can other approaches to justice, such as therapeutic jurisprudence and restorative justice, be incorporated into tort litigation - as by encouraging harmdoers to apologize and protecting their statements from expanded liability - but they have the power in many cases to preempt litigation altogether by facilitating settlement or discouraging the filing of a claim in the first place (see chapters by Robbennolt, Greene, \& Landsman). This would make trials both less likely to occur and less painful when they do occur (see chapter by Greene, this volume). Researchers would do well to heed Tomkins and Applequist's recommendation to devote more time and resources to studying justice issues in non-trial contexts.

The emphasis on juries also obscures the fact there are many other, potentially more beneficial and cost-effective, ways to improve the civil justice system. Improving jury instructions, mentioned above, is one example; the chapter by Bornstein and Robicheaux (this volume) mentions other possibilities, many of them endorsed by organizations such as the American Tort Reform Association, but which receive much less attention. For instance, promoting jury service and sound science in the courtroom are uncontroversial goals that could yield enormous benefits. Both would lead to a more efficient system, and the latter would undoubtedly lead to more just outcomes.

There are many procedures outside the litigation context that would further the aims of justice as well. In light of the small number of trials (especially jury trials), it is necessary to focus reform efforts where they can do the most good. In the healthcare context, that means worrying less about malpractice lawsuits and more about reducing medical errors and changing medical attitudes and culture (see chapters by Landsman and Miller). There are many medical errors (Institute of Medicine, 2000), but few lawsuits; so strategies should focus on preventing the injuries in the first place. Nor should physicians be singled out for their "juryphobia": It is rampant in society, afflicting product manufacturers, businesses, service providers, and govern- 
ments. Everyone has his or her favorite example of how juryphobia has gotten out of control and diminished our quality of life. One that hits close to home for me is that many golf courses no longer place water coolers along the course, due to fears that the water might somehow become contaminated and make an unsuspecting golfer sick. And excessive warnings are everywhere (e.g., "Do not place hands under lawnmower while blade is moving"). As in the case of medical malpractice, the specter of a jury trial, legal liability, and a large damage award loom large in these cases - but the problem goes well beyond the jury.

The excessive emphasis on physicians' liability in malpractice trials also ignores the much more common, and potentially more vexing, issue of medical injuries and evidence, as well as testimony by physician witnesses who are not party to the lawsuit. After all, trials involving physical or psychological (as opposed to financial or property) injury are going to contain testimony describing the nature and extent of the injury. Often, though not always, medical experts will provide testimony in these cases, in order to characterize or quantify the harm that has been done (Bornstein \& Greene, in press). There are many variables to consider in addressing the effect that such testimony is likely to have, especially when the injury's effects are not readily observable (Hans, this volume). Physicians have a much larger role to play in the civil justice system than merely as possible defendants.

\section{Conclusion}

Empirical research on civil juries is a relatively young field, dating back roughly to the 1950s (Kalven, 1958, 1964). The empirical study of civil justice is somewhat older, and philosophical discussions of justice go back thousands of years; but there is still much research to be done on these topics. In the present chapter, I have tried to identify some of the promising signs for the field as a whole, while also pointing out limitations and areas where there is room for improvement.

Questions of civil justice raise much larger issues than whether juries do a good or poor job and how we can improve their performance. They go to normative questions about what is fair and reasonable and the kind of society we wish to live in. Nonetheless, civil juries and civil justice are intertwined. Whether we like it or not, jurors are the poster children of our civil justice system. As psycholegal researchers, we should study more than just juries; but a better understanding of juries would go a long way toward the larger goal of achieving civil justice. 


\section{References}

Abramson, J. (1994). We, the jury: The jury system and the ideal of democracy. New York: Basic Books.

Benton, T. R., McDonnell, S., Ross, D. F., Thomas, W. N., \& Bradshaw, E. (2007). Has eyewitness research penetrated the American legal system? In R. C. L. Lindsay, D. F. Ross, J. D. Read, \& M. P. Toglia (Eds.), Handbook of eyewitness psychology, Vol. 2: Memory for people (pp. 453-500). Mahwah, NJ: Erlbaum.

Bliesener, T. (2006). Lay judges in the German criminal court: Social-psychological aspects of the German criminal justice system. In M. F. Kaplan \& A. M. Martin (Eds.), Understanding world jury systems through social psychological research. NewYork: Psychology Press.

Blumenthal, J. A. (2002). Law and social science in the twenty-first century. Southern California Interdisciplinary Law Journal, 12, 1-53.

Bornstein, B. H. (1999). The ecological validity of jury simulations: Is the jury still out? Law and Human Behavior, 23, 75-91.

Bornstein, B. H., \& Greene, E. (in press). Consulting on damage awards. Forthcoming in R. L. Wiener \& B. H. Bornstein (Eds.), Handbook of trial consulting. New York: Springer.

Bornstein, B. H., \& McCabe, S. G. (2005). Jurors of the absurd? The role of consequentiality in jury simulation research. Florida State University Law Review, 32, 443-467.

Diamond, S. S. (1997). Illuminations and shadows from jury simulation. Law and Human Behavior, 21, 561-571.

Diamond, S. S. (2003). Convergence and complementarity between professional judges and lay adjudicators. In P. van Koppen \& S. D. Penrod (Eds.), Adversarial vs. inquisitorial justice (pp. 321-332). New York: Springer.

Galanter, M. (2004). The vanishing trial: An examination of trials and related matters in federal and state courts. Journal of Empirical Legal Studies, 1, 459-570.

Greene, E., \& Bornstein, B. H. (2000). Precious little guidance: Jury instruction on damage awards. Psychology, Public Policy, and Law, 6, 743-768.

Greene, E., \& Bornstein, B. H. (2003). Determining damages: The psychology of jury awards. Washington, DC: American Psychological Association.

Guthrie, C., Rachlinski, J. J., \& Wistrich, A. J. (2001). Inside the judicial mind. Cornell Law Review, 86, 777-830.

Hans, V. P. (2006, Spring). The twenty-first century jury: Worst of times or best of times? Criminal Law Brief, 3-8.

Institute of Medicine (2000). To err is human: Building a safer health system. Retrieved March 9, 2007 from: http://www. iom. edu/object. file/master/4/117/0. pdf

Jonakait, R. N. (2003). The American jury system. New Haven, CT: Yale University Press.

Kalven, H. (1958). The jury, the law, and the personal injury damage award. Ohio State Law Journal, 19, 159-178.

Kalven, H. (1964). The dignity of the civil jury. Virginia Law Review, 50, 1055-1075.

Kaplan, M. F., \& Martin, A. M. (2006). Understanding world jury systems through social psychological research. New York: Psychology Press.

Kerr, N. L., \& Bray, R. M. (2005). Simulation, realism, and the study of the jury. In N. Brewer \& K. D. Williams (Eds.), Psychology and law: An empirical perspective (pp. 322-364). New York: Guilford.

Lawless, R. M., Robbennolt, J. K., \& Ulen, T. S. (in press). Empirical methods in law. New York: Aspen Publishers.

Merritt, D. J., \& Cihon, J. (1997). New course offerings in the upper-level curriculum: Report of an AALS survey. Journal of Legal Education, 47, 524-570. 
Miller, M. K., \& Bornstein, B. H. (2004). Juror stress: Causes and interventions. Thurgood Marshall Law Review, 30, 237-269.

Ogloff, J. R. P., \& Finkelman, D. (1999). Psychology and law: An overview. In R. Roesch, S. D. Hart, \& J. R. P. Ogloff (Eds.), Psychology and law: The state of the discipline (pp. 1-20). New York: Kluwer Academic/Plenum Publishers.

Philip Morris USA v. Williams, 127 S. Ct. 1057 (2007).

Post, L. (Nov. 10, 2004). Spelling it out in plain English. National Law Journal online.

Robbennolt, J. K. (2005). Evaluating juries by comparison to judges: A benchmark for judging? Florida State University Law Review, 32, 469-509.

Robbennolt, J. K., \& Studebaker, C. A. (1999). Anchoring in the courtroom: The effects of caps on punitive damages. Law and Human Behavior, 23,353-373.

Saks, M. J. (1989). Legal policy analysis and evaluation. American Psychologist, 44, $1110-1117$.

Saks, M. J. (1992). Do we really know anything about the behavior of the tort litigation system - and why not? University of Pennsylvania Law Review, 140, 1147-1292.

Sharkey, C. M. (2003). Punitive damages as societal damages. Yale Law Journal, 113, 347-453.

Sharkey, C. M. (2005). Unintended consequences of medical malpractice damages caps. New York University Law Review, 80, 391-512.

Sheinman, H. (2003). Tort law and corrective justice. Law and Philosophy, 22, 21-73.

State Farm Mutual Automobile Insurance Company v. Campbell, 123 S. Ct. 1513 (2003).

Sunstein, C., Hastie, R., Payne, J., Schkade, D., \& Viscusi, W. (2002). Punitive damages: How juries decide. Chicago, IL: University of Chicago Press.

Technical Working Group for Eyewitness Evidence (1999). Eyewitness evidence: A guide for law enforcement. Washington, DC: U. S. Department of Justice.

Tyler, T. R., Boeckmann, R. J., Smith, H. J., \& Huo, Y. J. (1997). Social justice in a diverse society. Boulder, CO: Westview Press.

Van Koppen, P., \& Penrod, S. D. (2003). Adversarial vs. inquisitorial justice. New York: Springer.

Vidmar, N. (2000). World jury systems. New York: Oxford University Press.

Vidmar, N., \& Hans, V. (2007). American juries: The verdict. Amherst, NY: Prometheus Press.

Wiener, R. L. (2007). Law and everyday decision making: Rational, descriptive, and normative models. In R. L. Wiener, B. H. Bornstein, R. Schopp, \& S. L. Willborn (Eds.), Social consciousness in legal decision making (pp. 3-32). New York: Springer. 